\title{
PENGARUH RESTRUKTURISASI ORGANISASI, BUDAYA ORGANISASI, DAN GAYA KEPEMIMPINAN TERHADAP KINERJA PEGAWAI DI KANTOR KECAMATAN MAYANGAN KOTA PROBOLINGGO
}

\author{
ROHIM* \\ DELLA ROSA GUNAWAN \\ Program Studi Ilmu Administrasi Negara \\ Sekolah Tinggi Ilmu Administrasi Pembangunan Jember \\ *Email: rohim.annida86@gmail.com
}

\begin{abstract}
ABSTRAK
Kinerja karyawan yang optimal dipengaruhi oleh beberapa aspek yang ada dalam organisasi, seperti restrukturisasi organisasi, budaya organisasi dan gaya kepemimpinan. Kajian ini bertujuan untuk menentukan dampak restrukturisasi organisasi, budaya organisasi dan gaya kepemimpinan terhadap kinerja pegawai di Kantor Kecamatan Mayangan Kota Probolinggo. Jenis penelitian ini adalah penjelasan kuantitatif. Populasi dalam penelitian ini berjumlah 98 orang, penentuan sampel menggunakan menggunakan teknik sampling acak sehingga responden yang diperoleh berjumlah 79 orang yang digunakan sebagai responden. Teknik pengumpulan data digunakan pengamatan, kuesioner dan studi kepustakaan. Teknik analisis data yang digunakan adalah analisis regresi linear berganda. Hasil uji regresi menunjukkan bahwa secara parsial variabel budaya organisasi tidak berpengaruh, sedangkan restrukturisasi organisasi dan gaya kepemimpinan berpengaruh positif dan signifikan terhadap kinerja pegawai.
\end{abstract}

Kata Kunci: Restrukturisasi Organisasi, Budaya Organisasi, Gaya Kepemimpinan, Kinerja Pegawai. 


\section{PENDAHULUAN}

Dalam organisasi dikatakan berhasil dalam mencapai tujuan dan program yang telah ditetapkan sebelumnya, jika individu yang bekerja di dalam organisasi dapat melakukan tugas mereka dengan benar, sesuai dengan bidang masingmasing dan tanggung jawab. Sehubungan dengan tugas yang dilakukan dengan baik, diperlukan pegawai yang memiliki semangat pengabdian dan disiplin yang tinggi.

Hal ini dapat dicapai, antara lain melalui jaminan hukum dalam bentuk kebijakan dan peraturan, keberadaan kerjasama yang baik, dan teladan kepemimpinan melalui sikap, perilaku dan memberikan motivasi kepada bawahan.

Goleman dalam Hadian (2015) berpendapat bahwa tugas pemimpin adalah untuk menciptakan resonansi, suasana positif bagi semua sumber daya manusia dalam organisasi untuk terus mengikat diri mereka sendiri dan mengembangkan kinerja terbaik untuk organisasi. Jadi pemimpin memiliki peran inti aspek manajemen sumber daya manusia dalam operasionalisasi atmosfer kerja untuk keberhasilan suatu organisasi. Selanjutnya Alberto et al. dalam Widhi (2015) menjelaskan bahwa gaya kepemimpinan seseorang sangat berpengaruh pada kinerja bawahan. Gaya kepemimpinan dapat dilihat dalam dua cara, yaitu gaya kepemimpinan formal dan informal. Kepemimpinan formal lebih ditekankan pada sistem yang diadopsi oleh sebuah agensi, tetapi sifatnya yang kaku cenderung kadang tidak sesuai dengan kondisi karyawan. Sementara kepemimpinan cenderung informal cenderung untuk menekankan pembelajaran dari para pemimpin, sehingga para pemimpin dianggap sebagai model, sementara karyawan memiliki kebebasan untuk menjadi kreatif dalam menyelesaikan pekerjaan.

Kepemimpinan adalah kemampuan untuk memotivasi, mempengaruhi, mengarahkan, dan berkomunikasi dengan bawahan, selain para pemimpin juga harus memiliki perilaku atau cara kepemimpinan yang disesuaikan dengan situasi dan kondisi, adalah fleksibel untuk dapat menyesuaikan 
dan beradaptasi dengan lingkungan Bawahan.

Kepemimpinan menentukan arah dan kinerja karyawan dalam sebuah organisasi. Kepemimpinan yang baik akan menentukan kinerja pegawai dalam menentukan keberhasilan suatu lembaga/organisasi. Kemampuan para pemimpin untuk memotivasi bawahan adalah keterampilan manajerial yang perlu dikuasai oleh setiap manajer/kepala organisasi. Dengan memahami peran penting motivasi, pemimpin akan mampu mengembangkan kinerja kerja bawahan dan dapat menjadi

\section{TINJAUAN PUSTAKA}

\subsection{Manajemen Sumber Daya Manusia}

Cushway dalam Priyono (2016:4) mendefinisikan MSDM sebagai 'Part of the process that helps the organization achieve its objectives'. Pernyataan ini dapat diterjemahkan sebagai 'bagian dari proses yang membantu organisasi mencapai tujuannya'.

Menurut Stoner MSDM meliputi penggunaan SDM secara produktif dalam mencapai tujuan- kepuasan kerja (Sujak, 1990:21). Keselarasan antara kepemimpinan dengan pegawai yang memiliki sifat dan sikap yang konstruktif dan aktif, tinggi tanggap, inisiatif dan kreatif dan kepekaan untuk beradaptasi dengan lingkungan akan mendukung keberhasilan organisasi di masa depan. Dengan uraian di atas dapat dilihat bahwa restrukturisasi organisasi, budaya organisasi dan gaya kepemimpinan memiliki pengaruh terhadap kinerja karyawan dalam melaksanakan tugasnya.

tujuan organisasi dan pemuasan kebutuhan pekerja secara individual. Stoner menambahkan bahwa karena berupaya mengintegrasikan kepentingan orgarnisasi dan pekerjanya, maka MSDM lebih dari sekadar seperangkat kegiatan yang berkaitan dengan koordinasi SDM organisasi. MSDM adalah kontributor utama bagi keberhasilan organisasi. Oleh karena itu, jika MSDM tidak efektif dapat menjadi 
hambatan utama dalam memuaskan pekerja dan keberhasilan organisasi.

Berdasarkan beberapa pendapat para ahli diatas dapat ditarik kesimpulan bahwa manajemen sumber daya manusia yaitu suatu proses pendayagunaan sumber daya manusia (SDM) yang ada secara efektif dan efisien untuk mencapai tujuan organisasi.

\subsection{Restrukturisasi Organisasi}

Restrukturisasi

menurut

pendapat Hasibuan (2001:90) adalah "Perubahan struktur suatu organisasi baik secara vertikal maupun horizontal, agar lebih efektif membantu tercapainya tujuan". Restrukturisasi ini dilakukan karena struktur organisasi (chartorganizatio) tidak efektif lagi, akibat adanya kemajuan atau kemunduran perusahaan.

Menurut Stoner et.al (1996:109112), terdapat 3 (tiga) pendekatan antara lain:

1. Pendekatan pada Perubahan Struktural

Pendekatan struktural ini dibagi menjadi 3 (tiga), yaitu: Pertama, termasuk perubahan struktural yang diciptakan melalui penerapan Desain Organisasi, tujuannya untuk menentukan dengan jelas tanggungjawab para anggota organisasi. Kedua, melalui Desentralisasi yang didasarkan pada gagasan bahwa pembentukan unit-unit organisasi yang lebih kecil dan berdiri sendiri akan memperkuat motivasi para anggota. Ketiga, Modifikasi Arus Kerja (mengubah arus kerja) dalam organisasi dengan pertimbangan bahwa arus kerja yang tepat secara langsung akan menghasilkan peningkatan produktivitas, moral dan kepuasan kerja.

2. Pendekatan pada Perubahan Teknologi

Perubahan teknologi yang tidak diselaraskan dengan perubahan struktur organisasi akan menimbulkan ketidakpuasan sehingga prestasi kerja menurun.

3. Pendekatan pada Perubahan Manusia

Pendekatan ini memiliki tujuan untuk secara langsung mengubah perilaku para 
karyawan dengan memuaskan perhatian pada skill, sikap persepsi, dan harapan sehingga mereka dapat bekerja lebih efektif. Sikap baru dan keahlian dapat memberi dorongan kepada karyawan untuk memprakarsai perubahan struktur dan teknologi organisasi.

Penelitian ini menggunakan indikator yang dikemukakan oleh Stoner yaitu: Perubahan pada struktural, perubahan teknologi, dan perubahan pada sumber daya manusia.

\subsection{Budaya Organisasi}

Budaya organisasi dikemukakan oleh Cartwright dalam Wardiah (2016) sebagai soft side dan hard side yang di dalamnya tercakup struktural, sistem produksi, teknologi, dan desain. Hal ini menunjukkan bahwa budaya organisasi diartikan sebagai nilainilai dasar bagaimana anggota berperilaku dan bertindak dalam sebuah organisasi. Akan tetapi, nilai disini sulit diamati dalam waktu singkat, karena nilai dalam hal ini bersifat intrinsik atau tidak kasat mata.

Denison dan Mishra (2000:168), mengemukakan bahwa budaya organisasi mempunyai empat prinsip integratif mengenai hubungan timbal balik antara budaya organisasi dan efektifitas kerja organisasi. Keempat prinsip ini diberi nama 4 (empat) sifat utama (main cultural traits) yang menyangkut keterlibatan (involvement), konsistensi (concistency), adaptabilitas (adaptibility), dan misi (mission).

\subsection{Gaya Kepemimpinan}

Harsey dan Blanchard (Simamora: 2005) mengemukakan 4 (empat) gaya kepemimpinan yaitu:

1. Gaya kepemimpinan Direktif Gaya kepemimpinan ini ditandai dengan adanya komunikasi satu arah. Pimpinan membatasi peranan bawahannya apa, kapan, dimana dan bagaimana sesuatu tugas dilaksanakan. Pemecahan masalah dan pengambilan keputusan semata-mata menjadi tanggung jawab pemimpin.

2. Gaya kepemimpinan Konsultatif 
Pimpinan memberikan arahan yang cukup besar kepada bawahannya baik dan proses pembuatan keputusan maupun dalam pelaksanaanya. Pemimpin menggunakan konsultasi dua arah dan memberikan support terhadap bawahannya.

3. Gaya kepemimpinan Partisipatif Pada gaya kepemimpinan kontrol atas pemecahan masalah dan pengambilan keputusan antara pimpinan dan bawahan bersifat seimbang. Pimpinan dan bawahan sama-sama terlibat dalam proses pengambilan keputusan. Komunikasi dua arah semakin menigkat, pimpinan seamakin mendengarkan pendapat bawahannya secara insentif, keikutsertaan bawahan dalam memecahkan masalah dan mengambil keputusan semakin bertambah.

4. Gaya kepemimpinan Delegatif Pemimpin berusaha mendiskusikan masalah-masalah yang dihadapi dengan bawahan dan selanjutnya mendelegasikan pengambilan keputusan seluruhnya kepada bawahannya.
Bawahan mempunyai wewenang untuk melaksanakan keputusan seluruhnya kepada bawahan dan member wewenang untuk melaksanakan keputusan itu tanpa banyak campur tangan pimpinan. Hal ini dilakukan karena bawahan dipandang telah memiliki kecakapan dan dapat dipercaya untuk memikul tanggung jawab dalam mengarahkan dan mengelola dirinya sendiri garis kebijakan pimpinan.

Penelitian ini menggunakan indikator yang dikemukakan oleh Harsey dan Blanchard yaitu: Gaya kepemimpinan direktif, konsultatif, partisipatif dan direktif.

\subsection{Kinerja Pegawai}

Menurut Mangkunegara (2007:67) adalah "Hasil kerja secara kualitas dan kuantitas yang dicapai oleh seorang pegawai dalam melaksanakan tugasnya sesuai dengan tanggung jawab yang diberikan kepadanya". Pengertian ini menggambarkan bahwa kinerja merupakan hasil kerja, tanpa mempertimbangkan proses bekerja 
dalam pencapaian hasil kerja tersebut. Pengertian yang lain dikemukakan oleh Bernardin dan Russel (1998:378) yaitu "Performance is defined as the record of outcomes produced on a specified job function or activity during a specified time period" apabila diterjemahkan berarti kinerja dapat didefinisikan sebagai catatan

\section{METODE PENELITIAN}

Peneliti menggunakan jenis penelitian yang bersifat explanatory dengan pendekatan kuantitatif. Penelitian ini dilaksanakan di Kantor Kecamatan Mayangan Kota Probolinggo yang beralamat di Jalan Ikan Paus Nomor 34 Probolinggo. Operasional penelitian dimulai bulan September sampai dengan November 2018.

Populasi yang digunakan dalam penelitian ini berjumlah 98 Pegawai. Teknik yang digunakan dalam pengambilan sampel menggunakan rumus slovin sehingga ditemukan sampel sebanyak 79 orang, kemudian tentang hasil-hasil yang diperoleh dari fungsi-fungsi pekerjaan atau aktivitas tertentu selama kurun waktu tertentu.

Penelitian ini dalam mengukur kinerja pegawai menggunakan teorinya Dharma diantaranya adalah sebagai berikut: Kuantitas, Kualitas dan ketepatan waktu.

untuk menentukan sampel / responden dilakukan dengan cara random sampling, dimana untuk menentukan reponden dilakukan secara acak sehingga ditemukan 79 responden.

Dalam penelitian ini peneliti menggunakan jenis data primer dimana data ini merupakan jawaban dari kuesioner yang dibagikan kepada responden serta data sekunder dimana data ini dapat diperoleh dari arsip-arsip atau dokumen lainnya yang dibutuhkan dalam penelitian ini. 


\section{HASIL PENELITIAN DAN PEMBAHASAN}

\subsection{Uji Validitas}

Berdasarkan hasil uji validitas, menunjukkan bahwa variabel independen yaitu variabel restrukturisasi organisasi $\left(\mathrm{X}_{1}\right)$, budaya organisasi $\left(\mathrm{X}_{2}\right)$ dan gaya kepemimpinan $\left(\mathrm{X}_{3}\right)$ serta variabel dependen yakni variabel kinerja pegawai (Y) mempunyai $r$ hitung lebih besar daripada $\mathrm{r}$ tabel yang artinya indikator yang digunakan pada variabel penelitian ini adalah valid dan layak digunakan sebagai alat ukur penelitian.

\subsection{Uji Reliabilitas}

Berdasarkan hasil perhitungan uji reliabilitas menunjukkan bahwa seluruh variabel yang digunakan pada penelitian ini bersifat konsisten atau reliabel, hal tersebut terlihat dari nilai $\alpha>0,6$ yang artinya reliabel.

\subsection{Analisis Regresi Linier Berganda}

Tabel 1. Hasil Perhitungan Regresi Linier Berganda

\begin{tabular}{|l|l|r|r|c|}
\hline Variabel & \multicolumn{1}{|c|}{$\mathbf{B}$} & \multicolumn{1}{c|}{$\begin{array}{c}\text { t } \\
\text { hitung }\end{array}$} & $\mathbf{t}_{\text {tabel }}$ & Sig. \\
\hline Konstanta & 7,160 & 1,470 & 1,665 & 0,052 \\
\hline$\left(\mathrm{X}_{1}\right)$ & 0,265 & 2,234 & 1,665 & 0,028 \\
\hline$\left(\mathrm{X}_{2}\right)$ & 0,025 & 0,136 & 1,665 & 0,892 \\
\hline$\left(\mathrm{X}_{3}\right)$ & 0,386 & 3,229 & 1,665 & 0,002 \\
\hline & $\mathrm{R}$ & $=$ & 0,671 & \\
\hline & $\mathrm{R}^{2}$ & $=$ & 0,451 & \\
\hline & Standar & & & \\
& Error & $=$ & 0,429 & \\
\hline & F Hitung & $=$ & 20,504 & \\
\hline & Fsig. & $=$ & 0,000 & \\
\hline & $\mathrm{N}$ & $=$ & 79 & \\
\hline
\end{tabular}

Dari hasil Tabel 1 dapat dibuat persamaan regresi linier berganda sebagai berikut:

$$
\begin{aligned}
& \mathrm{Y}=7,160+0,265 \mathrm{X}_{1}+0,025 \\
& \mathrm{X}_{2}+0,386 \mathrm{X}_{3}+\mathrm{e}
\end{aligned}
$$

Dari persamaan diatas dapat dianalisis beberapa hal sebagai berikut:

a. Kinerja pegawai (Y), tanpa adanya budaya organisasi, 
restrukturisasi organisasi dan gaya kepemimpinan $\left(\mathrm{X}_{1}\right.$ dan $X_{2}=0$ ), maka kinerja hanya bernilai 7,160 , sedangkan bila masingmasing responden bertambah 1 poin untuk jawaban restrukturisasi organisasi, budaya organisasi dan gaya kepemimpinan $\left(\mathrm{X}_{1}, \mathrm{X}_{2}\right.$ dan $\mathrm{X}_{3}=79$ ), maka dapat diperkirakan tingkat kinerja akan naik menjadi:

$\mathrm{Y}=7,160+0,265 \mathrm{X}_{1}+$ $0,025 \mathrm{X}_{2}+0,386 \mathrm{X}_{3}$ $\mathrm{Y}=7,160+0,265(79)+$ $0,025(79)+0,386(79)$ $\mathrm{Y}=7,160+20,935+1,975$ $+30,494$ $\mathrm{Y}=60,564$

b. Koefisien regresi linier berganda sebesar (0,265), $(0,025)$ dan $(0,386)$ mengindikasikan besaran pertambahan tingkat kinerja pegawai (Y) pada setiap pertambahan jawaban responden untuk variabel restrukturisasi organisasi $\left(\mathrm{X}_{1}\right)$, budaya organisasi $\left(\mathrm{X}_{2}\right)$ dan variabel gaya kepemimpinan $\left(\mathrm{X}_{3}\right)$.

c. Persamaan regresi linier berganda $Y=7,160+0,265$ $\mathrm{X}_{1}+0,025 \mathrm{X}_{2}+0,386 \mathrm{X}_{3}+$ e digunakan sebagai dasar untuk memperkirakan tingkat kinerja pegawai yang dipengaruhi oleh restrukturisasi organisasi $\left(\mathrm{X}_{1}\right)$, budaya organisasi $\left(\mathrm{X}_{2}\right)$ dan variabel gaya kepemimpinan $\left(\mathrm{X}_{3}\right)$ apakah sudah valid untuk diuji dan digunakan.

\subsection{Pembahasan}

\section{Pengaruh Restrukturisasi \\ Organisasi terhadap Kinerja}

Pada pengujian secara parsial (uji t) antara variabel restrukturisasi organisasi $\left(\mathrm{X}_{1}\right)$ terhadap kinerja pegawai (Y) diperoleh nilai siginifikansi $=0,028$. Nilai ini menunjukkan hubungan yang kuat positif antara $\left(\mathrm{X}_{1}\right)$ dan $(\mathrm{Y})$. Maksud kuat dan positif disini adalah terjadi hubungan yang searah antara variabel retrukturisasi organisasi dan kinerja, artinya bila nilai restrukturisasi organisasi naik maka 
tingkat kinerja akan naik secara signifikan. Indikator yang digunakan dalam pengukuran restrukturisasi organisasi ada 3 yaitu diantaranya perubahan struktur, perubahan teknologi dan perubahan sumber daya manusia.

Adapun urutan dari indikator yang paling berpengaruh terhadap kinerja adalah indikator perubahan struktur menduduki peringkat tertinggi dari variabel restrukturisasi organisasi dalam mempengaruhi kinerja yakni dari responden sebesar $78,5 \%$ positif menanggapi bahwa spesialisasi atau pembagian tenaga kerja sudah sesuai dengan pemecahan suatu alur penyelesaian pekerjaan, hal ini sejalan dengan pilihan responden, karena untuk memberikan kenyamanan bagi pegawai dalam melaksanakan tugas yaitu adanya jaminan "the right man on the right job / penempatan pegawai sesuai bidangnya". Pada tahun ini ada rekrutmen tenaga Pegawai Tidak Tetap (PTT) yang mempunyai keahlian di bidang Teknologi Informasi (TI) dan Akuntansi yang selanjutnya melewati seleksi yang ketat dan ditempatkan sesuai keahlian atau bidangnya. Hal ini bertujuan untuk mendukung kelancaran pelaksanaan tugas kantor sehari-hari, sehingga yang menjadi kendala selama ini bisa teratasi.

Selanjutnya adalah indikator perubahan teknologi sebesar $74,7 \%$ yaitu Dukungan Top Leader (Camat) kepada pegawai dalam membenahi fasilitas kantor dalam hal ini tekhnologi informasi sudah sangat memadahi, seperti pemasangan wifi baik di kantor Kecamatan Mayangan maupun Kantor Kelurahan SeKecamatan Mayangan, penambahan anggaran untuk pengadaan perangkat komputer maupun laptop yang diperuntukkan kepada setiap pegawai dalam rangka menunjang kinerja. Adanya fasilitas tersebut selain mendukung kinerja pegawai juga memberikan kenyamanan kepada masyarakat dalam menikmati pelayanan publik baik di Kantor Kecamatan Mayangan maupun Kantor Kelurahann se-Kecamatan Mayangan Kota Probolinggo.

Indikator perubahan sumber daya manusia sebesar $72,2 \%$ respon dari responden yaitu perubahan keterampilan sudah memberikan 
dampak positif kepada organisasi, dalam hal ini bisa dipastikan jika pegawai mempunyai keterampilan maka akan meningkatkan kinerja pegawai dalam melaksanakan tugas.

Adanya restrukturisasi organisasi pada awal tahun 2017 berdampak pada perubahan sumber daya manusia (SDM), hal ini seiring dengan adanya pengurangan seksiseksi baik yang ada di di Kantor Kecamatan Mayangan maupun Kantor Kelurahann se-Kecamatan Mayangan Kota Probolinggo sehingga mendorong pegawai meningkatkan kemampuan maupun keterampilan dalam melaksakan tugas pokok dan fungsinya.

Indikator berikutnya perubahan teknologi 69,6\% Dukungan pengetahuan komputer secara interen organisasi sudah dilaksanakan untuk pemahaman tentang komputer / Teknologi Informasi. Adanya rekrutmen pegawai di bidang Teknologi Informasi diharapkan membantu kelancaran pelaksanaan tugas kantor selain itu juga ditugaskan membantu rekan-rekan kerja yang masih belum menguasai Teknologi Informasi sehingga nantinya semua pegawai bisa menguasai Teknologi Informasi dan berdampak pada kinerja organisasi.

Dari beberapa penjelasan diatas, dapat dikembalikan kepada konsep awal penulis yang menyatakan restrukturisasi organisasi berpengaruh terhadap kinerja. Hal ini dapat dilihat berdasarkan perhitungan secara parsial maupun simultan diperoleh jawaban bahwa variabel restrukturisasi organisasi $\left(\mathrm{X}_{1}\right)$ menunjukkan hubungan yang kuat positif dengan variabel kinerja (Y) sebesar $\mathrm{r}=0,538$ dan terjadi hubungan yang searah antara variabel restrukturisasi organisasi dan kinerja, artinya bila nilai restrukturisasi organisasi naik maka tingkat kinerja akan naik secara signifikan dengan 3 (tiga) indikator dengan masing-masing nilai dari respon dari responden sebagai berikut: perubahan struktur 78,5\%, perubahan teknologi $74,7 \%$, dan perubahan sumber daya manusia $72,2 \%$. 


\section{Pengaruh Budaya Organisasi terhadap Kinerja}

Pada pengujian secara parsial (uji t) antara variabel budaya organisasi $\left(\mathrm{X}_{2}\right)$ terhadap kinerja pegawai (Y) diperoleh nilai siginifikansi sebesarr 0,892. Nilai ini menunjukkan hubungan yang negatif antara $\left(\mathrm{X}_{2}\right)$ dan $(\mathrm{Y})$. Maksud negatif disini terjadi hubungan yang tidak searah antara budaya organisasi $\left(\mathrm{X}_{2}\right)$ dengan kinerja pegawai (Y), artinya bila nilai budaya organisasi naik maka seharusnya nilai kinerja pegawai naik juga, namun disini tidak mengalami kenaikan secara siginifikan. Indikator yang digunakan dalam penelitian ini yaitu: Keterlibatan (involvement), Konsistensi (concistency), Adaptabilitas (adaptibility), dan Misi (mission).

Budaya organisasi di Kantor Kecamatan Mayangan kota Probolinggo masih belum berjalan secara optimal, hal ini bisa dilihat dari orientasi tim atau organisasi yang masih belum terealisasi, artinya masih ada sifat individualisme dalam melaksanakan program dan kegiatan yang telah ditetapkan. Selain itu pada item menciptakan perubahan masih mendapatkan nilai yang sedikit, artinya para pegawai di Kantor Kecamatan Mayangan Kota Probolinggo masih tergantung intruksi pimpinan dalam melaksanakan aktivitas atau kegiatan operasional baik itu secaraadministrasi maupun lapangan. Pimpinan / Camat sudah memberikan keleluasaan kepada pegawai dalam berinovasi dan berimprovisasi dalam melaksanakan tugas-tugas kantor namun tidak sesuai dengan harapan.

\section{Pengaruh}

Gaya

\section{Kepemimpinan}

terhadap

\section{Kinerja Pegawai}

Pada hasil analisis regresi secara parsial antara variabel gaya kepemimpinan $\left(\mathrm{X}_{3}\right)$ dengan kinerja (Y) diperoleh nilai siginifikansi sebesar 0,02. Nilai ini menunjukkan hubungan yang positif antara $\left(\mathrm{X}_{3}\right)$ dan (Y). Maksud positif disini adalah terjadi hubungan yang searah antara variabel gaya kepemimpinan dengan kinerja, artinya bila nilai gaa kepemimpinan naik maka kinerja akan anik secara signifikan. Indikator 
yang digunakan dalam pengukuran gaya kepemimpinan ada 4 (empat) indikator diantaranya mengarahkan, konsultasi, berpartisipasi dan delegasi.

Adapun urutan dari indikator yang paling berpengaruh terhadap kinerja adalah indikator delegasi mendapatkan respon sebesar 70,89\% dari responden positif menanggapi bahwa Pemimpin memberikan kewenangan dalam mengontrol pelaksanaan tugas sesuai dengan tanggung jawab, dalam hal ini responden menyatakan bahwa pimpinan (Camat) mengutamakan hasil akhir dengan memberikan kepercayaan kepada bawahan dalam melaksakan tugas. Tingkat kepercayaan pemimpin dalam memberikan tugas kepada bawahan sangat baik, hal tersebut dapat dilihat dari bagaimana pemimpin memberikan kesempatan dan kebebasan kepada bawahan atau pegawai dalam melaksanakan sendiri pekerjaan sesuai dengan keinginan pegawai namun tidak keluar dari ketentuan atau peraturan-peraturan yang ada dan pemimpin tidak melepas kontrolnya sebagai pimpinan. Pemimpin juga memberikan kewenangan kepada pegawai dalam mengontrol pekerjaan sesuai dengan tanggung jawabnya masing-masing. Pemimpin percaya terhadap kemampuan dan kemauan pegawai dalam menyelesaikan tugas dengan baik.

Selanjutnya $68,3 \%$ pada indikator yang sama pada item Pemimpin percaya kemampuan dan kemauan pegawai dalam melaksanakan tugas, disini bisa dipertegas lagi dengan adanya kepercayaan yang begitu besar dari seorang pimpinan kepada pegawai dalam menyelesaikan tugastugasnya. Mulai dari hal-hal mendasar seperti: kebersihan kantor, tidak adanya petugas khusus yang menangani masalah kebersihan kantor, namun dengan adanya kepercayaan yang besar kepada pegawai sehingga pegawai mempunyai rasa "sungkan" dalam diri pegawai sehingga pegawai dengan senang hati melaksanakan tugas tersebut meskipun statusnya sebagai Pegawai Negeri Sipil.

Selanjutnya adalah indikator berpartisipasi memperoleh $62,03 \%$ 
yaitu Pemimpin memberikan kebebasan mengeluarkan kritik atau saran yang membangun kemajuan organisasi, pimpinan dalam hal ini bukan tipe orang yang anti kritik, bisa dilihat dari respon dari responden yang begitu besar, dengan adanya pimpinan seperti itu membuat bawahan tidak canggung dalam menyampaikan uneg-uneg atau ide inovasi untuk kemajuan organisasi. Pemimpin bersedia mendengarkan pendapat dari bawahan, apabila dirasa pendapat tersebut tidak menyimpang dari norma yang ada dalam organisasi. Selain itu, permasalahan yang terjadi dalam organisasi umumnya diatasi dengan berdiskusi bersama bawahan untuk mencapai solusi yang terbaik bagi kemajuan organisasi.

Selanjutnya ada 4 (empat) item yang memperoleh nilai yang sama sebesar 56,96\% yakni Pemimpin mengamati pekerjaan pegawai (indikator mengarahkan), Pemimpin bersedia mendengarkan pendapat atau saran dari bawahan, Pemimpin memberikan solusi dan bantuan ketika pegawai menemui kendala (indikator konsultasi) dan Pemimpin melibatkan bawahan dalam mencari solusi permasalahan administrasi yang terjadi (indikator berpartisipasi).

Dari beberapa penjelasan diatas, dapat dikembalikan kepada konsep awal penulis yang menyatakan gaya kepemimpinan berpengaruh terhadap kinerja. Hal ini dapat dilihat berdasarkan perhitungan secara parsial maupun simultan diperoleh jawaban bahwa variabel gaya kepemimpinan $\left(\mathrm{X}_{2}\right)$ menunjukkan hubungan yang kuat positif dengan variabel kinerja $(\mathrm{Y})$ sebesar $\mathrm{r}=0,635$ dan terjadi hubungan yang searah antara variabel gaya kepemimpinan dan kinerja, artinya bila nilai gaya kepemimpinan naik maka tingkat kinerja akan naik secara signifikan dengan 4 (empat) indikator sebagai berikut: delegasi $(70,89 \%, 68,3 \%$ dan 58,23\%) berpartisipasi 62,03, mengarahkan dan konsultasi sama $56,96 \%$. 


\section{KESIMPULAN DAN SARAN}

\subsection{Kesimpulan}

Berdasarkan hasil penelitian dan pembahasan, maka dapat ditarik kesimpulan sebagai berikut:

1. Restrukturisasi

organisasi berpengaruh terhadap kinerja. Hal ini bisa dibuktikan dari hasil uji regresi linier berganda yang menunjukkan pengaruh yang positif antara restrukturisasi organisasi dan kinerja dengan model searah yang artinya apabila nilai restrukturisasi organisasi naik maka nilai kinerja akan naik secara signifikan.

2. Budaya Organisasi tidak berpengaruh terhadap kinerja pegawai. Hal ini bisa dilihat dari hasil uji regreso berganda yang menunjukkan pengaruh yang negatif antara budaya organisasi dan kinerja dengan model yang tidak searah artinya nilai budaya organisasi naik namun nilai kinerja pegawai tidak mengalami kenaikan yang signifikan.

3. Gaya kepemimpinan berpengaruh terhadap kinerja. Hal ini bisa dibuktikan dari hasil uji regresi linier berganda yang menunjukkan pengaruh yang positif antara gaya kepemimpinan terhadap kinerja dengan model searah yang artinya apabila nilai gaya kepemimpinan naik maka nilai kinerja akan naik secara signifikan. Indikator yang digunakan dalam gaya kepemimpinan diantaranya mengarahkan, konsultasi, berpartisipasi dan delegasi yang mana masing-masing memiliki pengaruh yang berbeda-beda terhadap kinerja pegawai Kantor Kecamatan Mayangan Kota Probolinggo.

\subsection{Saran}

Sumbangsih saran yang dapat diberikan oleh penulis dalam penelitian ini adalah:

1. Hasil penelitian menunjukkan indikator perubahan sumber daya manusia yang paling rendah dikarenakan sikap pegawai belum memberikan dampak positif kepada organisasi, oleh karena itu disarankan kepada Camat Mayangan perlunya untuk 
membentuk lingkungan kerja yang positif yang mana akan berpengaruh pada hubungan yang kuat dengan rekan kerja, maupun dengan pemangku kepentingan lainnya. Berhasil atau gagalnya suatu organisasi ditentukan oleh soliditas pegawai di lingkungan kerja. Setiap bidang atau seksi harus saling mengisi dan berkomunikasi secara aktif dalam melaksanakan kegiatan. Selain itu setiap pegawai dibiasakan membuat pola kerja mendahulukan hal-hal penting atau prioritas, dalam hal ini pegawai membuat checklist apa saja yang akan dikerjakan, sehingga memudahkan dalam menyelesaikan pekerjaan yang sudah menjadi prioritas. Budaya

\section{DAFTAR PUSTAKA}

Bernardin and Russel. 1993. Human Resource Management. New Jersey: International Editions Upper Saddle River.

Denison dan Mishra. 2000. Organizational culture and organizational effectiveness: a theory and some preliminary empirical evidence. School of business administration. University of Michigan. kerja organisasi perlu dijaga, dibutuhkan kesadaran dari setiap elemen, menghindari sikap saling menyalahkan karena akan memperburuk hubungan kerja antar pegawai dan pada akhirnya akan membahayakan keutuhan organisasi.

2. Penelitian dengan bahasan budaya organisasi, restrukturisasi organisasi dan gaya kepemimpinan menarik untuk dilakukan penelitian lanjutan, karena masih banyak hal yang masih bisa diungkap, dalam hal ini peneliti selanjutnya bisa menggunakan metode penelitian gabungan yaitu kuantitatif dan kualitatif sehingga penelitian selanjutnya bisa mendalam.

Dharma. 2005. Manajemen Perilaku Organisasi: Pendayagunaan Sumber Daya Manusia. Jakarta: Erlangga.

Hadian, D.2015. Pengaruh Kepemimpinan, Struktur Organisasi dan Budaya Organisasi terhadap Kinerja Dinas serta Implikasinya pada Pelayanan Publik.Jurnal STIEP Pasundan, 3(1). 
Hasibuan, Malayu S.P. 2001. Manajemen Sumber Daya Manusia. Jakarta: Bumi Aksara.

Kusdi. 2011. Teori Organisasi dan Administrasi. Jakarta: Salemba Humanika.

Mangkunegara, A.P. 2007.Manajemen Sumber Daya Manusia Perusahaan.Cetakan Ketiga.Bandung: Rosdakarya.

Mulyadi, D. 2015. Perilaku Organisasi dan Kepemimpinan Pelayanan. Bandung: Alfabeta.

Priyono dan Marnis. 2016. Manajemen Sumber Daya Manusia. Sidoarjo: Zifatama Publisher.

Simamora, H.2005. Manajemen Sumber Daya Manusia. Yogyakarta:SKPN.

Stoner, James A.F., Freeman, R. Edward and Gilbert, Daniel R. 1996.Manajemen. Jakarta: PT. Prenhallindo.

Sujak, A.1990.Kepemimpinan Manajer. Jakarta: Rajawali Press.

Tiyanto. 2010. Tantangan Manajemen Sumber Daya Manusia Era Abad 21. Palu: Edukasi Mitra Grafika.

Wahjosumidjo. 2006. Kepemimpinan kepala sekolah: tinjauan teoritik danpermasalahannya. Jakarta: Raya Grafindo Persada.

Wardiah. 2016. Teori Perilaku dan Budaya Organisasi. Bandung: Pustaka Setia.

Widhi, Saputro Nugroho and Setyawati, Erma. 2015. Pengaruh Independensi, Gaya Kepemimpinan, Komitmen Organisasi dan Pemahaman Good Governance terhadap
Kinerja Auditor Pemerintah: Studi Empiris pada BPKP Perwakilan Jawa Tengah. Jurnal Manajemen dan Bisnis, 19 (1). 